\title{
Analisis Karakteristik Vibrasi pada Paper Dryer Machine untuk Deteksi Dini Kerusakan Spherical Roller Bearing
}

\author{
Harry Prayoga Setyawan, Dedi Suryadi* \\ Departemen Teknik Mesin, Fakultas Teknik, Universitas Bengkulu \\ Jl. WR. Supratman Kandang Limun, Bengkulu 38371A, Indonesia \\ *E-mail: dedi_suryadi@unib.ac.id
}

\begin{abstract}
High level vibration can cause defects on machines in industry. Bearing is one of the important components having high level vibration. Unpredicted defect on bearing is dangerous because it can stop process in industry. Basically, defects on bearing can be identified based on vibration level. In this paper, defect on spherical roller bearing of paper dryer machine will be analyzed by using vibration testing. The censors are put on radial and axial direction on bearing. Analyzer used to capture signal is Emerson CSI 2130 in order to capture vibration signal. Then, vibration level is compared to vibration standard ISO 10816-3 to know if defect occurs or not. Moreover, spectrum is analyzed to identify type to defects. Also, bearing defects are determined according to inner diameters, outer diameters, numbers of ball, and shaft speed. As results, spherical roller bearing of paper dryer machine has defect on inner race, outer race and ball.
\end{abstract}

Key words: Roller Bearing; Predictive Maintenance;Spectrum; Vibration Monitoring

\begin{abstract}
Abstrak
Getaran berlebih dapat menyebabkan kerusakan pada mesin-mesin di industri. Salah satu komponen mesin yang sering mengalami getaran lebih adalah bantalan. Kerusakan yang tidak terpantau pada bantalan sangat membahayakan mesin karena dapat mengakibatkan mesin berhenti beroperasi. Pada dasarnya kerusakan pada bantalan dapat diidentifikasi berdasarkan sinyal getaran. Pada penelitian ini, pengujian getaran akan dilakukan untuk mendeteksi kerusakan pada bantalan spherical roller pada mesin paper dryer. Untuk mencuplik data, sensor getaran diletakan di arah aksial dan radial pada bantalan. Analyzer yangdigunakan untuk mengolah sinyal adalah Emerson CSI 2130. Hasil sinyal yang diperoleh kemudian dibandingkan dengan standar level getaran ISO 10816-3 untuk menyatakan apakah mesin mengalami kerusakan atau tidak. Selanjutnya, spektrum sinyal getaran dianalisis untuk menentukan jenis kerusakan pada bantalan. Kerusakan pada bantalan ditentukan berdasarkan diameter dalam, diameter luar bantalan, jumlah bola dan putaran poros. Hasil pengujian menunjukkan bahwa bantalan spherical roller pada mesin paper dryer mengalami kerusakan pada lintasan dalam, lintasan luar dan bola.
\end{abstract}

Kata kunci: Roller Bearing; Predictive Maintenance; Spektrum Vibrasi; Vibration Monitoring

\section{Pendahuluan}

Mesin-mesin modern dirancang untuk berjalan secara otomatis, sehingga interaksi antara manusia (operator) dan mesin tidak lagi efektif dan ekonomis. Mesin-mesin modern beroperasi pada putaran/kecepatan tinggi, dimana getaran yang timbul banyak yang berfrekuensi tinggi dan tidak lagi dapat dibedakan oleh indra manusia, sehingga dibutuhkan alat untuk mendeteksi dan mengukurnya. Oleh karena itu untuk mengatasi salah satu permasalahan di atas dikembangkan metode untuk mendeteksi jenis kerusakan dan tingkat kerusakan bantalan bola dari karakteristik sinyal vibrasinya. Selanjutnya metode ini banyak diaplikasikan pada condition based maintenance yang ekonomis. Teknisi maintenance bertugas untuk memastikan paper dryer rollerss bekerja dengan baik. Di lapangan teknisi melakukan pengecekan rutin yang terjadwal untuk melihat kondisi mesin. Pengecekan meliputi pengecekan oli, temperatur, dan getaran pada paper dryer rollerss. Teknisi yang melakukan pengukuran diharapkan mengetahui penyebab vibrasi yang muncul dari data sebagai sumber referensi [1].

Analisa vibrasi sangat penting karena salah satu indikator yang baik untuk mendeteksi masalah mekanis untuk peralatan berputar (Rotating Equipment), karena getaran suatu mesin yang disebabkan oleh gaya berulang seperti ketakseimbangan, misalgment, poros bengkok, kerusakan bantalan, kelonggaran mekanik, gear aus, kavitasi dan resonansi [2]. Analisis getaran menganalisa pola getaran berdasarkan parameter-parameter getaran seperti frekuensi, amplitudo, dan phasa. Perubahan terhadap parameter tersebut menunjukkan adanya kelainan pada mesin yang dapat 
diidentifikasi sebagai kerusakan mesin [3]. Oleh karena itu, pada penelitian ini akan mendeteksi kerusakan spherical roller bearing pada paper dryer berdasarkan sinyal getaran yang hasilkan oleh mesin saat beroperasi.

\section{Material dan metode penelitian}

\subsection{Skema Pengujian}

Paper Dryer yang diteliti terdapat pada group rollers 3 dioperasikan dengan motor listrik AC dan menggunakan gearbox untuk mengatur rasio perputaran drive gear. Drive gear memutar group stage 3 yang terdiri dari 8 dryer rollers. Adapun skema kerja Paper Dryer dapat dilihat pada Gambar 1.

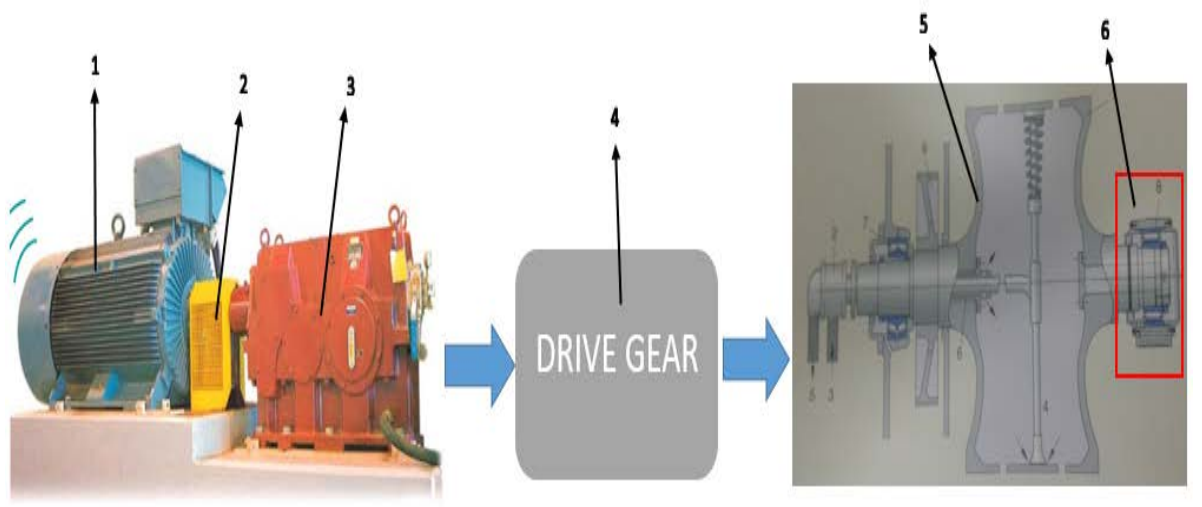

Keterangan:

$1=$ Motor AC

2 = Kopling Flens

$3=$ Gearbox

$4=$ Drive Gear

$5=$ Dryer Roller

$6=$ Tending Side Bearing

Gambar 1. Skema Kerja Paper Dryers [4]

\subsection{Skema Pengukuran}

Pengukuran vibrasi Paper Dryer dilakukan pada Mounting Tending Side Bearing. Pengukuran hanya dilakukan pada bagian ini dikarenakan pada bagian Drive Side Bearing terdapat Drive Gear yang terbuka sehingga tidak memungkinkan dilakukan pengukuran disana. Penempatan sensor tranduser diletakkan di Mounting Tending Side Bearing. Pengukuran dilakukan dengan 3 arah, yaitu arah radial vertikal, radial horizontal, dan aksial. Alat ukur yang digunakan yaitu CSI 2130 Machinery Health Analyzer. Hasil pengukuran vibrasi dalam bentuk velocity (kecepatan) dan dianalisa dengan software AMS Suite pada komputer. Skema pengukuran vibrasi pada Mounting Bearing Tending Side dapat dilihat pada Gambar 2.
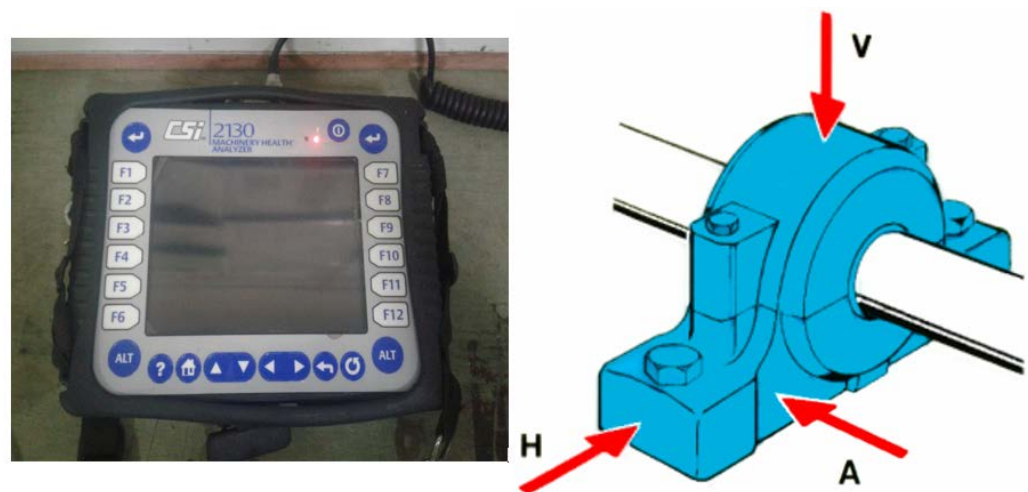

Gambar 2. Pengukuran Vibrasi pada Mounting Bearing Tending Side [5]

Alat ukur vibrasi yang digunakan adalah Emerson CSI 2130. Sebelum dilakukan pengukuran CSI 2130 dikalibrasi dengan mengamati linearitas hasil pengukuran dan sensitivitas range pengukuran vibrasi. Emerson CSI 2130 dapat dilihat pada Gambar 3.

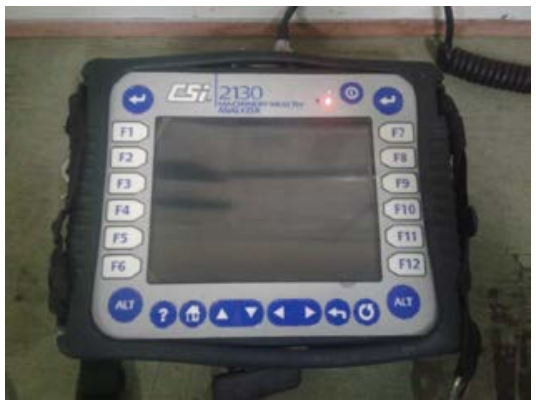

Gambar 3. Emerson CSI 2130 Machinery Health Analyzer 


\subsection{Standar Pengukuran Getaran}

Nilai efektif kecepatan getaran digunakan untuk menilai kondisi mesin. Standar Vibrasi ISO 10816-3 digunakan sebagai referensi untuk menentukan level vibrasi mesin. Standar Vibrasi ISO 10816-3 dapat dilihat pada Gambar 4. Karena motor yang digunakan untuk menggerakkan paper dryers memiliki daya output 65 kw dengan base plate tipe rigid, sehingga standar vibrasi ISO 10816-3 masuk dalam kategori Group 2.

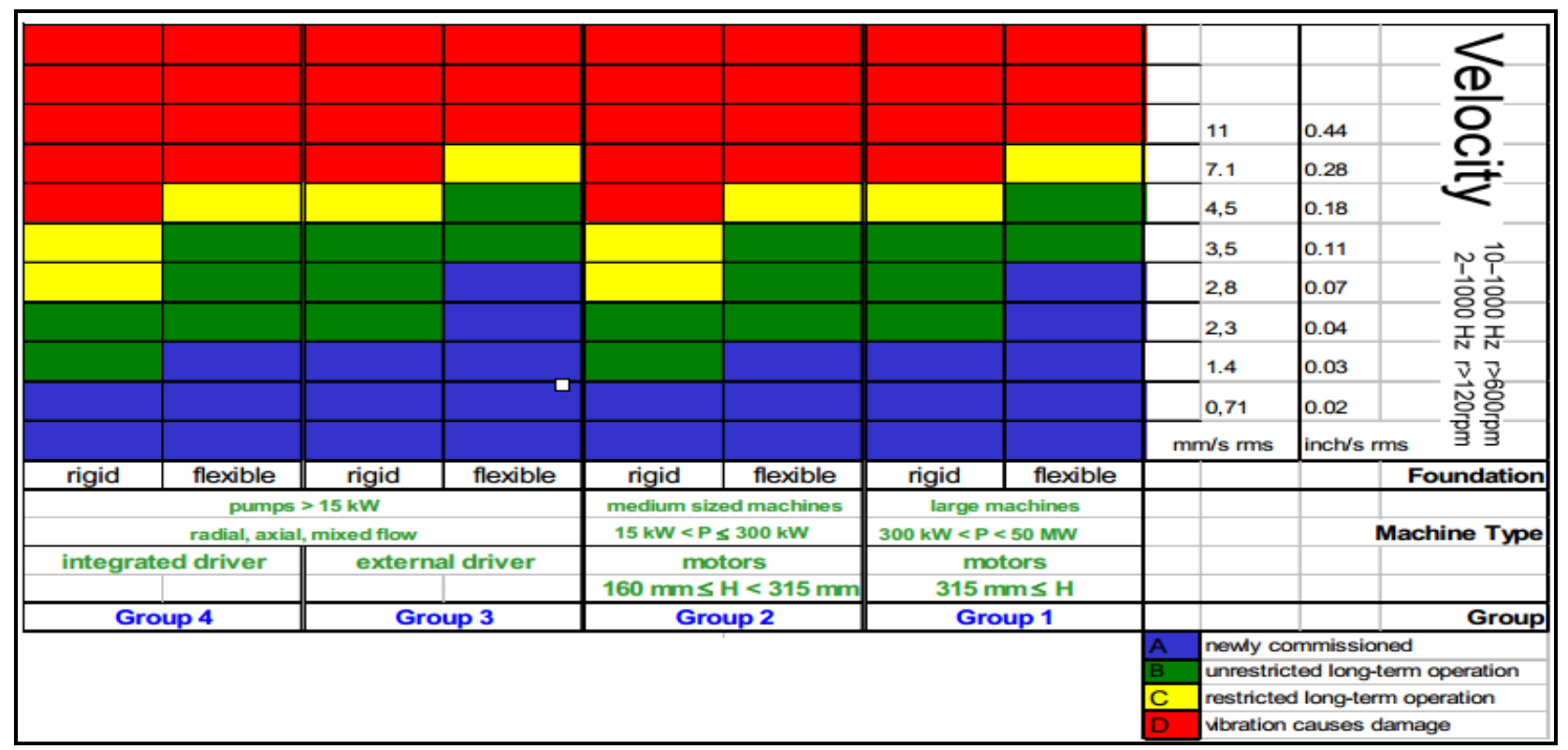

Gambar 4. Standar Vibrasi ISO 10816-3 [6]

\section{Hasil dan pembahasan}

\subsection{Data Penelitian}

Pada penelitian ini, motor yang digunakan untuk menggerakkan paper dryer rollerss memiliki daya output 65 kw dengan base plate tipe rigid. Berdasarkan standar vibrasi ISO 10816-3, motor ini termasuk dalam kategori Group 2. Tabel 1 menyajikan kondisi amplitudo getaran yang telah diukur berdasarkan standar vibrasi ISO 10816-3 sesuai dengan level getarannya. Hasil pengukuran getaran terjadi kenaikan amplitudo secara signifikan yang telah melewati batas danger level vibrasi IV yaitu 4,5 mm/s. Frekuensi cacat bearing SKF-23138CC dan cacat bearing SKF-23032CC dapat dilihat pada Tabel 2 dan Tabel 3.

Tabel 1. Amplitudo Getaran pada Paper dryer rollerss

\begin{tabular}{|c|c|c|c|c|c|c|c|}
\hline \multirow{3}{*}{ No. } & \multirow{3}{*}{ KOMPONEN } & \multicolumn{6}{|c|}{ VELOCITY (mm/s) } \\
\hline & & \multicolumn{2}{|c|}{ RADIAL (H) } & \multicolumn{2}{|c|}{ RADIAL (V) } & \multicolumn{2}{|c|}{ AXIAL } \\
\hline & & RUSAK & BARU & RUSAK & BARU & RUSAK & BARU \\
\hline 1 & Bearing SKF-23138CC & 1,44 & 2,66 & 0,82 & 0,57 & 4,62 & 1,94 \\
\hline 2 & Bearing SKF-23032CC & 1,44 & 2,52 & 0,8 & 0,58 & 4,6 & 1,93 \\
\hline \multicolumn{8}{|c|}{ Keterangan } \\
\hline & & \multicolumn{6}{|c|}{ Nilai Vibrasi pada Mesin yang Baru Bekerja } \\
\hline & & \multicolumn{6}{|c|}{$\begin{array}{l}\text { Nilai Vibrasi Kategori Alarm, namun Masih Diizinkan untuk Beroperasi dalam Jangka } \\
\text { Waktu yang Tak Terbatas }\end{array}$} \\
\hline & & \multicolumn{6}{|c|}{$\begin{array}{l}\text { Nilai Vibrasi Kategori Alarm, namun Masih Diizinkan untuk Beroperasi dalam Jangka } \\
\text { Waktu yang Terbatas }\end{array}$} \\
\hline & & \multicolumn{6}{|c|}{ Nilai Vibrasi yang Menyebabkan Kerusakan (Warning/Danger Level) } \\
\hline
\end{tabular}

Tabel 2. Frekuensi Cacat Bearing SKF-23138CC

\begin{tabular}{|c|c|c|c|c|c|}
\hline HARMONICS & SHAFT SPEED & TRAIN (FTF) & SPIN (BSF) & OUTER (BPFO) & INNER (BPFI) \\
\hline 1 & 1,00 & 0,44 & 4,02 & 9,68 & 12,32 \\
\hline 2 & 2,00 & 0,88 & 8,04 & 19,36 & 24,64 \\
\hline 3 & 3,00 & 1,32 & 12,06 & 29,04 & 36,96 \\
\hline 4 & 4,00 & 1,76 & 16,08 & 38,72 & 49,28 \\
\hline 5 & 5,00 & 2,20 & 20,10 & 48,40 & 61,60 \\
\hline
\end{tabular}


Tabel 3. Frekuensi Cacat Bearing SKF-23032CC

\begin{tabular}{|c|c|c|c|c|c|}
\hline HARMONICS & SHAFT SPEED & TRAIN (FTF) & SPIN (BSF) & OUTER (BPFO) & INNER (BPFI) \\
\hline 1 & 1,00 & 0,451 & 5,02 & 12,18 & 14,82 \\
\hline 2 & 2,00 & 0,902 & 10,05 & 24,37 & 29,63 \\
\hline 3 & 3,00 & 1,354 & 15,07 & 36,55 & 44,45 \\
\hline 4 & 4,00 & 1,805 & 20,10 & 48,73 & 59,27 \\
\hline 5 & 5,00 & 2,256 & 25,12 & 60,91 & 74,09 \\
\hline
\end{tabular}

\subsection{Analisis Spektrum Getaran}

\subsubsection{Ciri Getaran Kerusakan Bearing SKF-23138CC}

\section{a. Pengukuran Horizontal}

Spektrum vibrasi kerusakan bola BSF bearing SKF-23138CC arah horizontal dapat dilihat pada Gambar 5. Pengukuran vibrasi secara horizontal pada Bearing SKF-23138CC menunjukkan amplitudo sebesar 1,44 mm/s (ISO 10816-3 Level Vibrasi II). Frekuensi kerusakan bola bearing BSF 4,020 Orders. Ciri kerusakan bola bearing timbul harmonik pada $1 \mathrm{X}$ BSF, 3X BSF, 6X BSF, 9X BSF, dan 12X BSF.

Gambar 6 menunjukkan spektrum vibrasi kerusakan inner race BPFI bearing SKF-23138CC arah horizontal. Pengukuran vibrasi secara horizontal pada Bearing SKF-23138CC menunjukkan amplitudo sebesar 1,44 mm/s (ISO 10816-3 Level Vibrasi II). Frekuensi kerusakan inner race BPFI 12,32 Orders. Ciri kerusakan inner race timbul harmonik pada 1X BPFI, 2X BPFI, 3X BPFI, 4X BPFI, dan 6X BPFI.

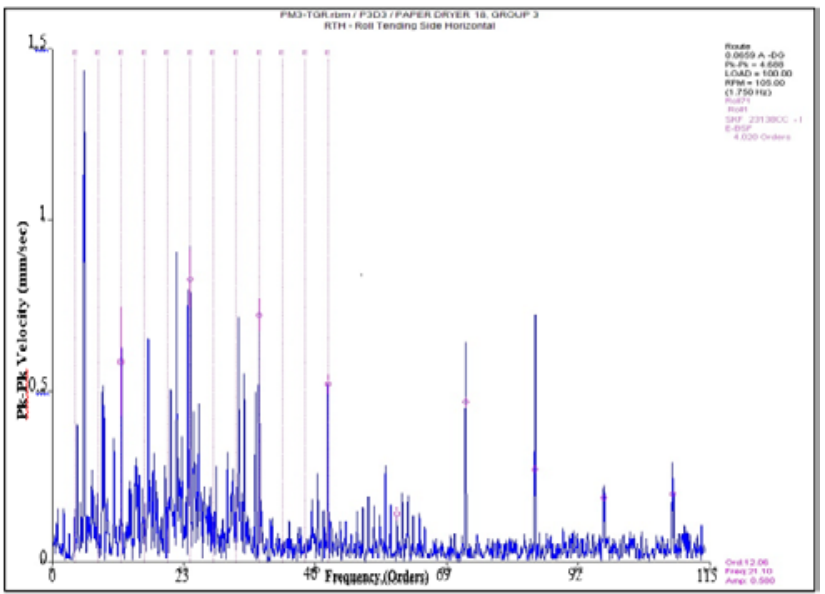

Gambar 5. Spektrum Vibrasi BSF Bearing SKF23138CC Horizontal

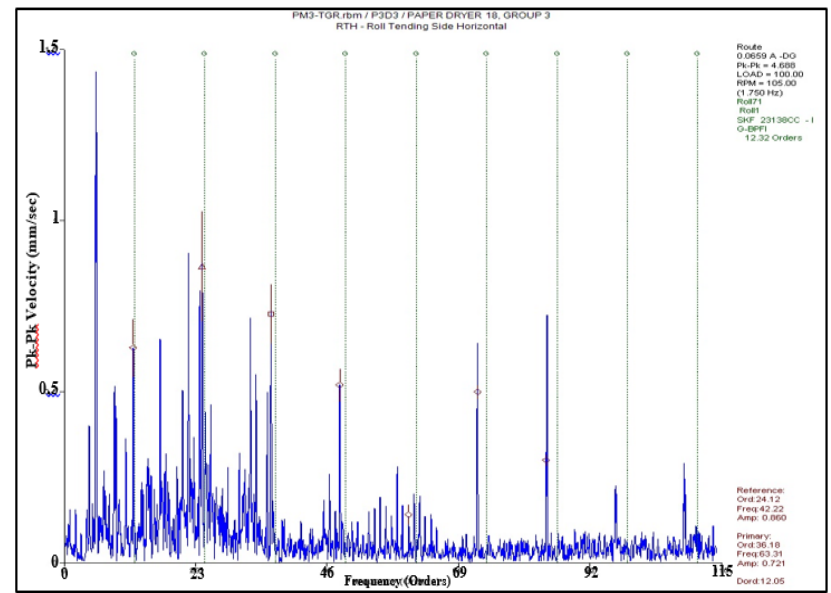

Gambar 6. Spektrum Vibrasi BPFI Bearing SKF23138CC Horizontal

\section{b. Pengukuran Vertikal}

Spektrum vibrasi kerusakan bola BSF bearing SKF-23138CC arah vertikal dapat dilihat pada Gambar 7. Pengukuran vibrasi secara vertikal pada Bearing SKF-23138CC menunjukkan amplitudo sebesar 0,82 mm/s (ISO 10816-3 Level Vibrasi I). Frekuensi kerusakan bola bearing BSF 4,020 Orders. Ciri kerusakan bola bearing timbul harmonik pada $1 \mathrm{X}$ BSF, 3X BSF, BSF RPM, 9X BSF, dan 12X BSF.

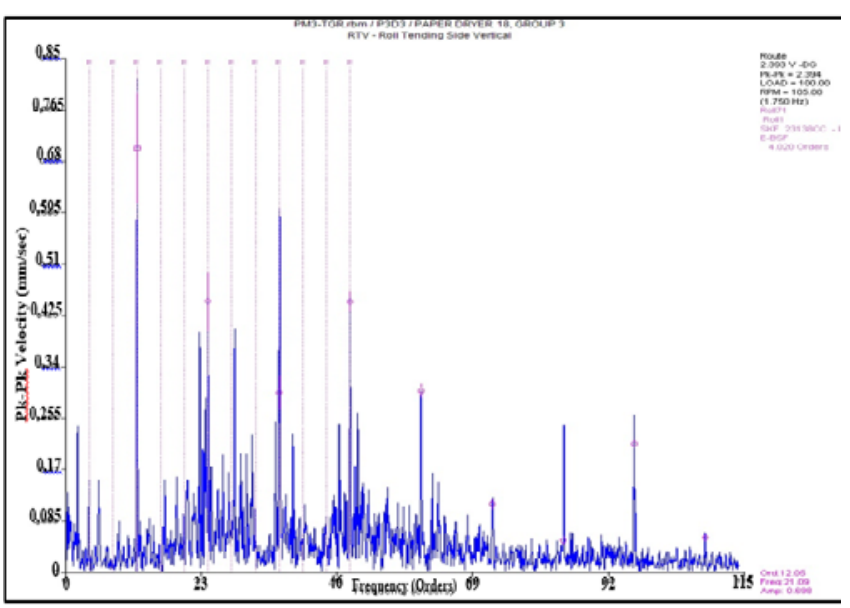

Gambar 7. Spektrum Vibrasi BSF Bearing SKF23138CC Vertikal

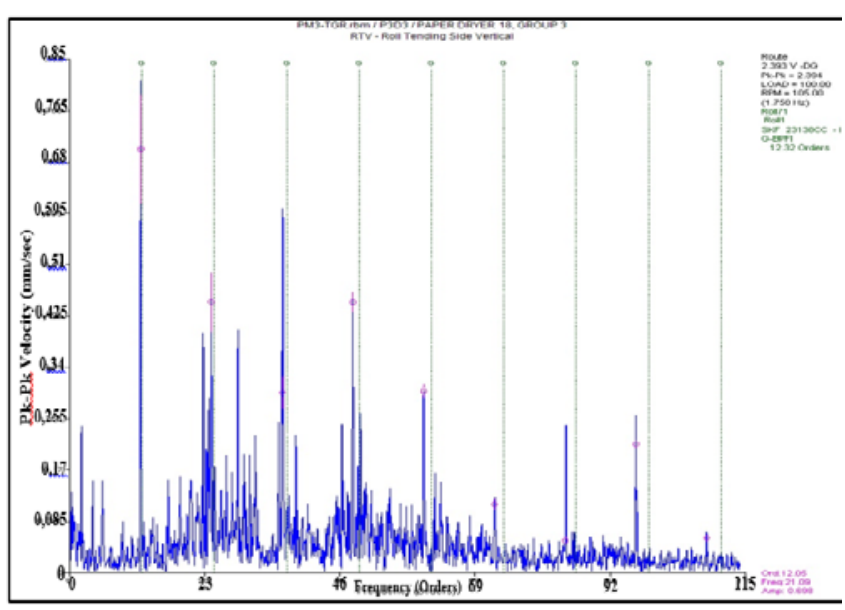

Gambar 8. Spektrum Vibrasi BPFI Bearing SKF23138CC Vertikal 
Gambar 8 menunjukkan spektrum vibrasi inner race BPFI bearing SKF-23138CC arah vertikal. Pengukuran vibrasi secara vertikal pada Bearing SKF-23138CC menunjukkan amplitudo sebesar 0,82 mm/s (ISO 10816-3 Level Vibrasi I). Frekuensi kerusakan inner race BPFI 12,32 Orders. Ciri kerusakan inner race timbul harmonik pada $1 \mathrm{X}$ BPFI, 2X BPFI, 3X BPFI, dan 4X BPFI.

\section{c. Pengukuran Aksial}

Gambar 9 menunjukkan spektrum vibrasi kerusakan bola BSF bearing SKF-23138CC arah aksial. Pengukuran vibrasi secara aksial pada Bearing SKF-23138CC menunjukkan amplitudo sebesar 4,62 mm/s (ISO 10816-3 Level Vibrasi IV). Frekuensi kerusakan bola bearing BSF 4,020 Orders. Ciri kerusakan bola bearing timbul harmonik pada 1X BSF, 3X BSF, 6X BSF, 9X BSF, dan 12X BSF.

Spektrum vibrasi inner race BPFI bearing SKF-23138CC arah vertikal dapat dilihat pada Gambar 10. Pengukuran vibrasi secara vertikal pada Bearing SKF-23138CC menunjukkan amplitudo sebesar 4,62 mm/s (ISO 10816-3 Level Vibrasi IV). Frekuensi kerusakan inner race BPFI 12,32 Orders. Ciri kerusakan inner race timbul harmonik pada $1 \mathrm{X}$ BPFI, 2X BPFI, dan 3X BPFI.

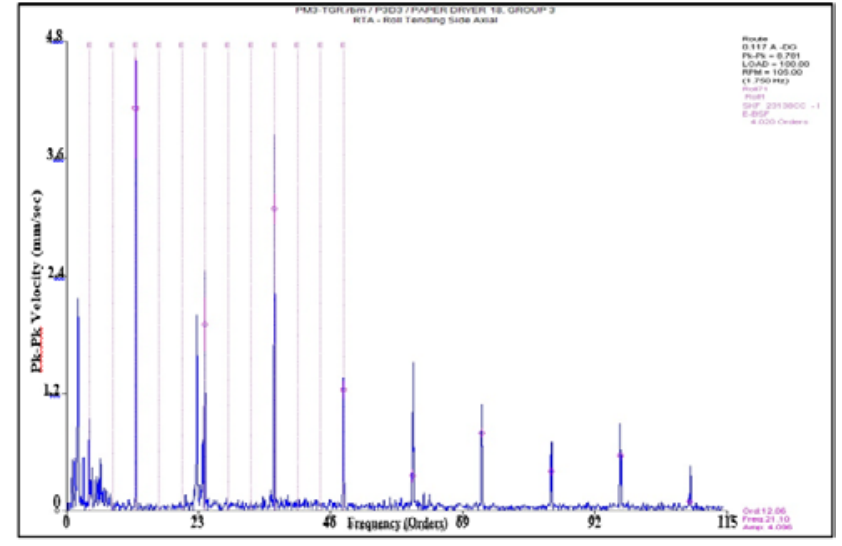

Gambar 9. Spektrum Vibrasi BSF Bearing SKF23138CC Aksial

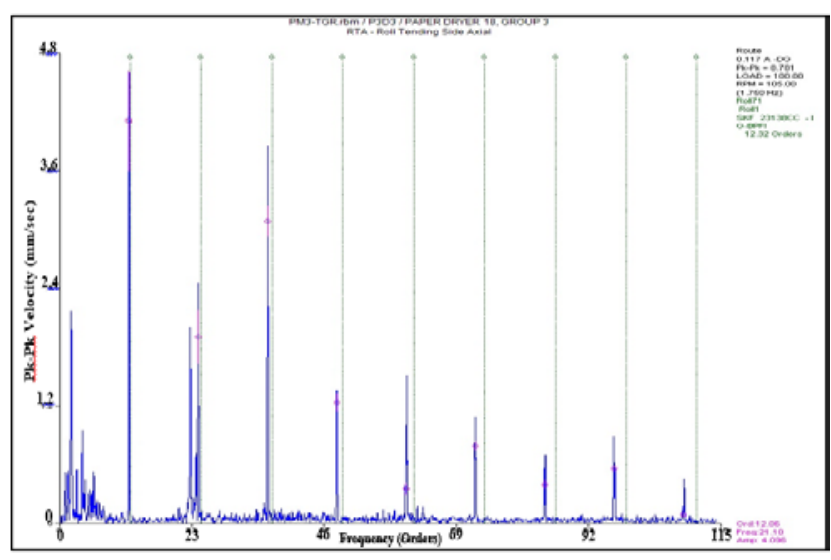

Gambar 10. Spektrum Vibrasi BPFI Bearing SKF23138CC Aksial

\section{d. Bearing SKF-23138CC Kondisi Baru}

Gambar 11 menunjukkan spektrum Vibrasi Bearing SKF-23138CC Aksial dalam kondisi baru. Hasil pengukuran vibrasi secara aksial pada Bearing SKF-23138CC diperoleh nilai amplitudo sebesar 4,62 mm/s. Berdasarkan standar vibrasi ISO 10816-3 nilai tersebut termasuk dalam level vibrasi IV yang dapat menyebabkan kerusakan pada mesin. Setelah penggatian dengan bearing baru, hasil pengukuran getaran pada sumbu aksial menghasilkan amplitudo sebesar $1,94 \mathrm{~mm} / \mathrm{s}$ (ISO 10816-3 Level Vibrasi II).

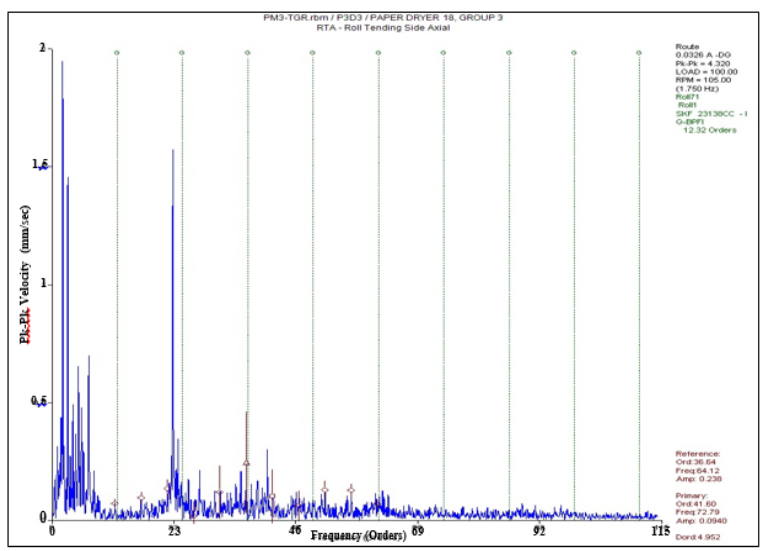

Gambar 11. Spektrum Vibrasi Bearing SKF-23138CC Aksial Kondisi Baru

\subsubsection{Ciri Getaran Kerusakan Bearing SKF-23032CC}

\section{a. Pengukuran Horizontal}

Spektrum vibrasi kerusakan outer race BPFO bearing SKF-23032CC arah horizontal dapat dilihat pada Gambar 12. Pengukuran vibrasi secara horizontal pada Bearing SKF-23032CC menunjukkan amplitudo sebesar 1,44 mm/s (ISO 
10816-3 Level Vibrasi II). Frekuensi kerusakan outer race BPFO 12,182 Orders. Ciri kerusakan outer race timbul harmonik pada 1X BPFO, 2X BPFO, 3X BPFO, 4X BPFO, 6X BPFO, dan 7X BPFO.

\section{b. Pengukuran Vertikal}

Gambar 13 menyajikan spektrum vibrasi kerusakan outer race BPFO bearing SKF-23032CC arah vertikal. Pengukuran vibrasi arah vertikal pada Bearing SKF-23032CC menunjukkan nilai amplitudo sebesar 1,42 mm/s (ISO 10816-3 Level Vibrasi II). Frekuensi kerusakan outer race BPFO 12,182 Orders. Ciri kerusakan outer race timbul harmonik pada $1 \mathrm{X}$ BPFO, 2X BPFO, 4X BPFO, 5X BPFO, dan 8X BPFO.

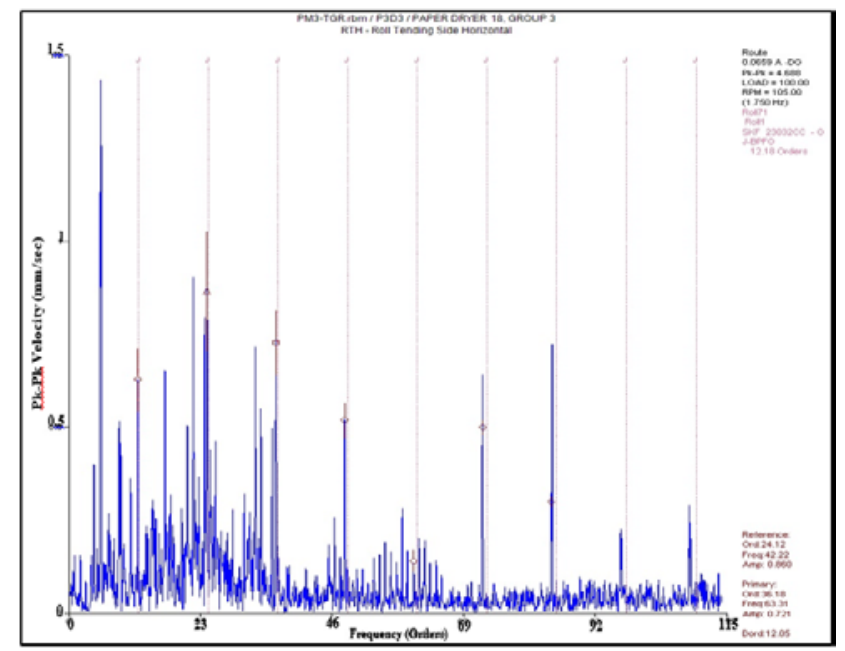

Gambar 12. Spektrum Vibrasi BPFO Bearing SKF23032CC Horizontal

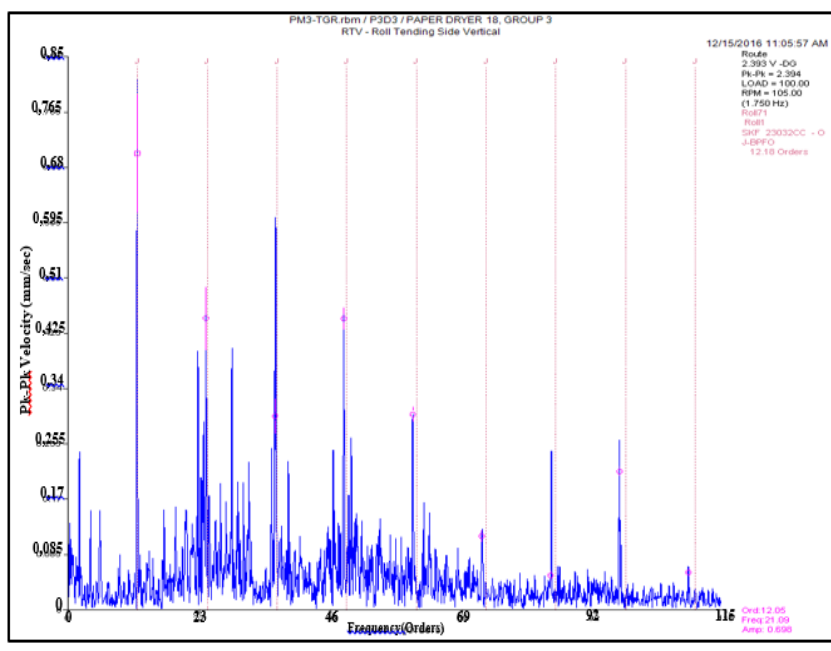

Gambar 13. Spektrum Vibrasi BPFO Bearing SKF23032CC Vertikal

\section{c. Pengukuran Aksial}

Gambar 14 menanpilkan spektrum vibrasi kerusakan outer race BPFO bearing SKF-23032CC arah aksial. Pengukuran vibrasi secara aksial pada Bearing SKF-23032CC menunjukkan nilai amplitudo sebesar 4,6 mm/s (ISO 10816-3 Level Vibrasi IV). Frekuensi kerusakan outer race BPFO 12,182 Orders. Ciri kerusakan outer race timbul harmonik pada 1X BPFO, 2X BPFO, 3X BPFO, 4X BPFO, 5X BPFO, 6X BPFO, 7X BPFO, dan 8X BPFO.

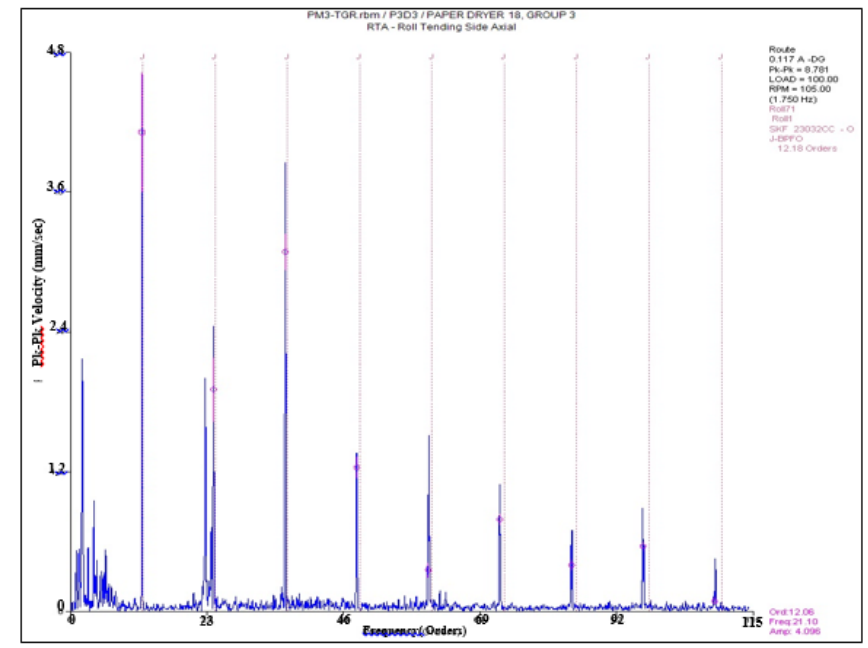

Gambar 14. Spektrum Vibrasi BPFO Bearing SKF-23032CC Aksial

\section{d. Bearing SKF-23032CC Baru}

Gambar 15 menunjukkan spektrum Vibrasi Bearing SKF-23032CC arah aksial dalam kondisi baru . Hasil pengukuran vibrasi secara aksial pada Bearing SKF-23138CC diperoleh nilai amplitudo sebesar 4,6 mm/s. Berdasarkan standar vibrasi ISO 10816-3, nilai tersebut termasuk dalam level vibrasi IV yang dapat menyebabkan kerusakan pada mesin. Langkah selanjutnya adalah melakukan pergantian bearing yang dilanjutkan dengan pengujian level getarannya. Hasil pengukuran getaran arah sumbu aksial menghasilkan amplitudo sebesar 1,93 mm/s (ISO 10816-3 Level Vibrasi II). Ini menandakan bahawa mesin dalam kondisi aman dan jangka waktu penggunaan tidak terbatas. Namun amplitudo dari sumber vibrasi lain tetap ada. 


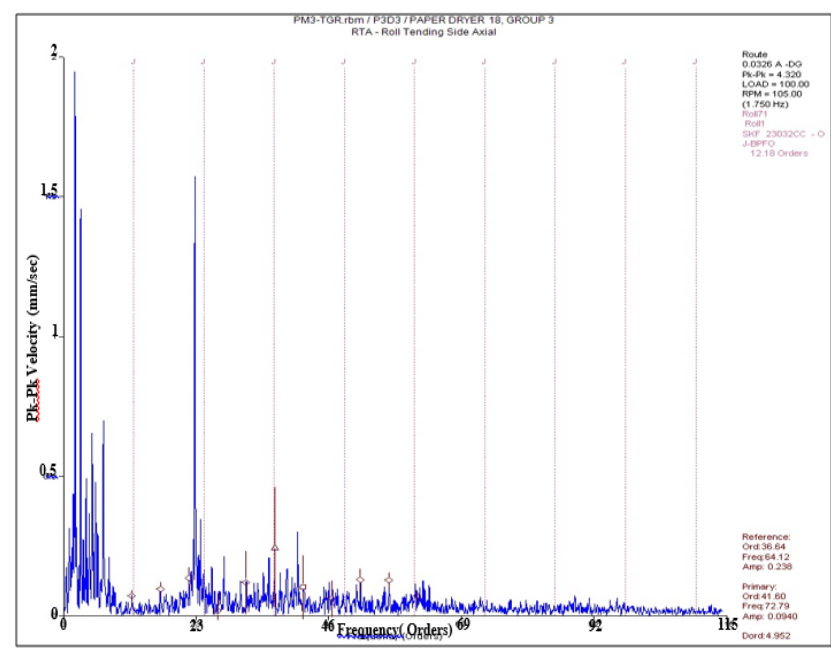

Gambar 15. Spektrum Vibrasi Bearing SKF-23032CC Aksial Kondisi Baru

\subsubsection{Analisa Kerusakan Bearing}

Dari data hasil pengukuran vibrasi menunjukkan adanya nilai High Frequency Detection (HFD) berada di ambang batas. Bearing SKF-23138CC berada di bagian Drive Side yang memiliki beban kerja menerima beban putaran gear secara langsung. Kerusakan komponen terjadi pada Bearing SKF-23138CC yaitu bola (BSF) pada 4,020 Orders dan inner race (BPFI) pada 12,32 Orders. Cacat pada bola dan inner race mengakibatkan keausan dan goresan. Kerusakan pada Bearing SKF-23138CC dapat dilihat pada Gambar 16.

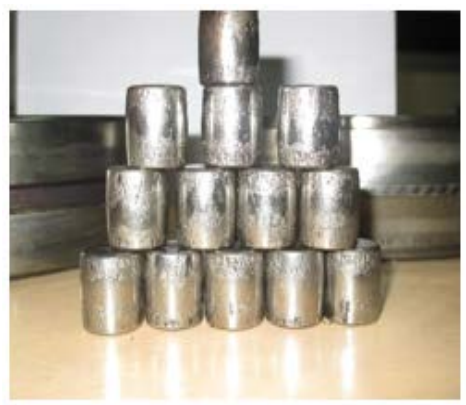

(a)

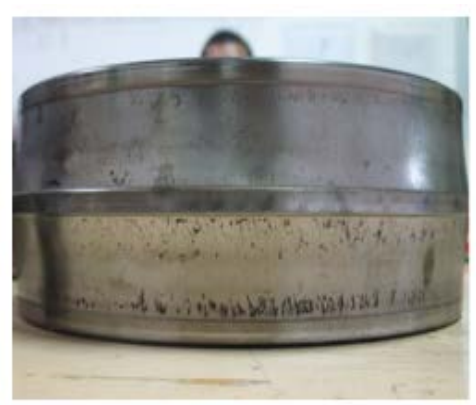

(b)

Gambar 16. Kerusakan Bearing SKF-23138CC; (a) Bola, (b) Inner Race

Bearing SKF-23032CC berada di bagian Tending Side sebagai komponen yang ikut memutar (driven). Kerusakan komponen pada Bearing SKF-23032CC yaitu outer race (BPFO) pada 12,182 Orders. Berdasarkan pengamatan di lapangan, cacat pada outer race disebabkan oleh sistem lubrikasi bearing yang tersumbat dan bercampur dengan air. Goresan pada outer race hanya terdapat di bagian dasar disebabkan oleh zona pembebanan (load zone) tertinggi berada di bagian dasar bearing. Kerusakan pada Bearing SKF-23032CC dapat dilihat pada Gambar 17.

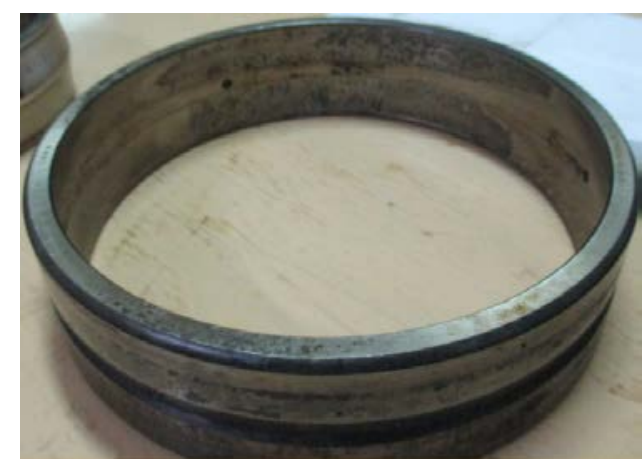

Gambar 17. Kerusakan Bearing SKF-23032CC Bagian Outer Race

Berdasarkan pengamatan spektrum vibrasi pada Paper Dryers No.18 nilai amplitude tertinggi pada pengukuran vibrasi sumbu aksial berada di level 4. Hal ini menunjukkan kategori vibrasi yang dapat merusak mesin dan telah 
melewati ambang batas standar ISO 10816-3 sehingga Bearing SKF-23138CC dan Bearing SKF- 23032CC perlu dilakukan penggantian. Penggantian dilakukan satu assembly Paper Dryer Rollers.

Setelah dilakukan penggantian komponen pada saat breakdown maintenance, pengukuran vibrasi dilakukan kembali sebagai trending yang terjadi pada Paper Dryer. Hasil pengamatan spektrum vibrasi setelah dilakukan penggantian unit menunjukkan cacat yang terjadi pada Bearing SKF 23138CC dan Bearing SKF-23032CC telah hilang. Hal ini ditunjukkan dengan hilangnya frekuensi cacat bearing dan sidebands vibrasi. Amplitudo tertinggi yang dihasilkan berada di level vibrasi aman.

Namun, muncul sinyal vibrasi lain (Gambar 15). Ciri getaran yang ditunjukkan sinyal ini merupakan ciri getaran unbalance pada poros yaitu timbul amplitudo pada 1X RPM. Unbalance ini timbul disebabkan pada saat pemasangan unit baru yang tidak memperhatikan faktor pengaruh sebagai penyebab munculnya unbalance. Sumber vibrasi lain dapat disebabkan dari Paper Dryer lain yang tergabung dalam Group Stage yang sama. Paper Dryer yang lain juga terdeteksi mengalami gejala kerusakan tapi tingkatnya tidak setinggi Paper Dryer No.18 sehingga hanya dilakukan pengamatan trending vibrasinya. Maka perlu dilakukan proses balancing agar paper dryer berfungsi secara normal dan tidak menimbulkan kerusakan lain.

\section{Kesimpulan}

Dari hasil analisis terhadap domain frekuensi terhadap kondisi bearing SKF-23138CC dan bearing SKF-23032CC pada paper dryer rollerss machine dapat disimpulan bahwa getaran pada paper dryer rollers secara keseluruhan menunjukkan adanya kerusakan bearing berdasarkan ciri getaran kerusakan mesin. Hasil pengukuran arah aksial menunjukkan nilai amplitudo yang telah melewati level vibrasi IV yang dapak menyebabkan kerusakan mesin. Selain itu, ciri getaran kerusakan bearing ditunjukkan dengan terjadinya getaran secara harmonik dan acak dan memiliki ciri spectrum vibrasi khusus antar tiap komponen bearing.

\section{Daftar Pustaka}

1] Risandriya, Sumantri, K., Suhendra, 2016, Analisa Spektrum Getaran Pada Pompa Sentrifugal menggunalan Fluke 810 Vibration Tester Berbasis Neural Network. Jurusan Teknik Elektro, Politeknik Negeri Batam. Batam

[2] Suhardjono, 2004, Analisis Sinyal Getaran untuk Menentukan Jenis dan Tingkat Kerusakan Bantalan Bola (Ball Bearing), Jurnal Teknik Mesin, Vol. 6, No. 2, Hal. 39-48.

[3] Arista, E.Y., Arifianto, D., Suyanto, 2012, Pengukuran Getaran dengan Vibrometer dan Akustik pada Mesin Pendorong Pokok (MPK) KRI Pulau Rupat-712 di Komando Armada RI Kawasan Timur Surabaya, Jurnal Teknik Pomits, Vol. 1, No. 1, Hal. 1-6.

[4] SKF, 2016, Rolling Bearings in Paper Machines.

[5] Crowford, A.R., Crowford S., 1992. "The Simplified Handbook of Vibration Analysis”, Volume 1, SCI, Knoxville.

[6] https://www.iso.org/standard/50528.html diakses pada Minggu, 18 Februari 2018 Pukul 22.00 WIB. 